\title{
Arsa Payı Karşılığı İnşaat Sözleşmesinde Yapı Kayıt Belgesi Alınmasının Yüklenicinin Edimini İfasına Etkisi*
}

\author{
Ayşe ARAT \\ Doç, Dr., Akdeniz Üniversitesi, Hukuk Fakültesi, Özel Hukuk Bölümü, aysearat@ akdeniz.edu.tr, (Sorumlu Yazar / \\ Corresponding Author)
}

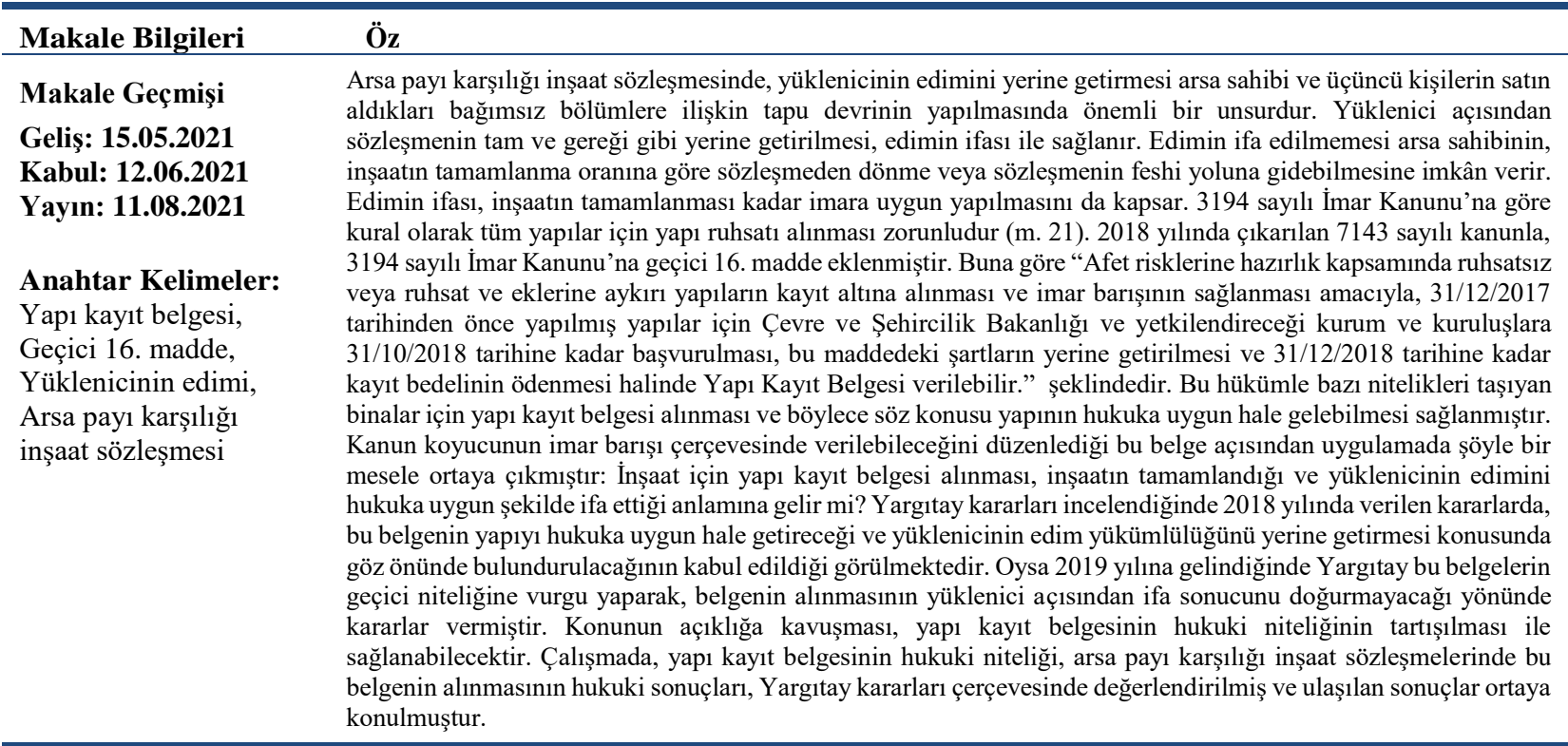

The Effect of Obtaining A Building Registration Certificate in The Construction Contract for Land Share on The Contractor's Performance

\begin{tabular}{|c|c|}
\hline Article Info & Abstract \\
\hline $\begin{array}{l}\text { Article History } \\
\text { Received: } 15.05 .2021 \\
\text { Accepted: } 12.06 .2021 \\
\text { Published: } \mathbf{1 1 . 0 8 . 2 0 2 1} \\
\text { Keywords: } \\
\text { Building registration } \\
\text { Certificate, Temporary } \\
\text { art. 16, Performance of } \\
\text { contractor }\end{array}$ & $\begin{array}{l}\text { In the construction contract in return for land share, the fulfillment of the contract by the contractor is an important } \\
\text { element in the transfer of the title deeds for the independent sections purchased by the land owner and third parties. } \\
\text { For the Contractor, the full and proper execution of the contract is provided by the performance of the act. In the } \\
\text { non-performance of obligation the action allows the landowner to rescission of the contract or to terminate the } \\
\text { contract depending on the completion rate of the construction. The execution of the act includes the completion of } \\
\text { the construction as well as the construction in accordance with the development. According to the Zoning Law No. } \\
3194 \text {, it is mandatory to obtain a building license for all buildings as a rule (art. 21). With the Law No. } 7143 \text { enacted } \\
\text { in } 2018 \text {, the temporary article } 16 \text { was added to the Zoning Law No. } 3194 \text {. With this provision, it has been ensured } \\
\text { that the building registration certificate is obtained for the buildings with certain qualities and thus the said building } \\
\text { becomes legal. Does obtaining a building registration certificate for construction mean that the construction has } \\
\text { been completed and the contractor has fulfilled its action in accordance with the law? When the decisions of the } \\
\text { Cassation Court are examined, it is seen that in the decisions made in } 2018 \text {, it is accepted that this document will } \\
\text { make the structure legal and it will be taken into account in the fulfillment of the contractor's performance } \\
\text { obligation. However, in } 2019 \text {, the Cassation Court emphasized the temporary nature of these documents and made } \\
\text { decisions that the receipt of the document would not result in execution for the contractor. In the study, the legal } \\
\text { nature of the building registration certificate, the legal consequences of obtaining this document in construction } \\
\text { contracts in return for land share were evaluated within the framework of the decisions of the Cassation Court and } \\
\text { the results reached were presented. }\end{array}$ \\
\hline
\end{tabular}

Atıf/Citation: Arat, A. (2021). “Arsa Payı Karşılığı İnşaat Sözleşmesinde Yapı Kayıt Belgesi Alınmasının Yüklenicinin Edimini İfasına Etkisi”, Necmettin Erbakan Üniversitesi Hukuk Fakültesi Dergisi, 4(2), s. 362-375.

Plagiarism: Bu makale intihal programında taranmış ve en az iki hakem incelemesinden geçmiştir. // This article has been scanned via a plagiarism software and reviewed by at least two referees.

* Bu makale 10-12 Nisan 2021 tarihinde Uluslararası Necmettin Erbakan Hukuk Kongresi’nde sunulan özet bildirinin genişletilmiş halidir. 


\section{GİRIŞ}

Doğru ve güvenli yapılaşma, bina standartlarının belirlenmesi ve bu standartlara uyulduğunun denetlenmesi ile mümkündür. Tarım ve diğer yerleşim dışı alanların korunması da doğru yapılaşmanın önemli unsurlarındandır. Ülkemizde bu amaçları sağlamak amacıyla İmar Kanunu çıkarılmıştır. Nitekim 3194 sayılı bu kanunun amaç başlıklı ilk maddesinde " yerleşme yerleri ile bu yerlerdeki yapılaşmaların; plan, fen, sağlık ve çevre şartlarına uygun teşekkülünü sağlamak amacıyla" düzenlendiği; ikinci maddesinde ise "Belediye ve mücavir alan sinırları içinde ve dışında kalan yerlerde yapılacak planlar ile inşa edilecek resmi ve özel bütün yapıların" bu Kanun hükümlerine tabi olduğu ifade edilmiştir ${ }^{1}$. Ancak ülkemizde kanunlarla getirilen bu sınırlamalara aykırı yapılaşmalarla maalesef çokça karşılaşılmakta, bunun önüne tam anlamıyla geçilememektedir. Bu yüzden sık sık imar affı olarak adlandırılan kanunlar çıkarılmaktadır. Böylece hukuka aykırı şekilde inşa edilen yapıların belli şartlar taşımak ve bazı şartları yerine getirmek kaydıyla hukuka uygun hale getirilmesi sağlanmaktadır. Genel olarak "yürürlükte olan kurallara uyulmayarak belli bir tarih kesitine kadar gerçekleşmiş yapılaşmanın, durum ve konumu itibariyle yasada belirtilen koşullara uygun olanların bağışlanması ve korunması"2 şeklinde tanımlanabilecek imar affında kanun koyucu, fiili durumu hukuki duruma dönüştürmeye çalışmakta ve geçmişte kalan uyuşmazlıkların üzerinden zaman geçmesine rağmen sürdürülmesini istemeyerek, toplumsal yararın bu yönde olduğu düşüncesiyle hareket etmektedir ${ }^{3}$. Oysa toplumsal yarar hukuka aykırı yapının hukuka uygun sayılmasında değil, etkin bir denetimle hukuka aykırı yapılaşmaya izin verilmemesindedir. Bugüne kadar imar affına ${ }^{4}$ yönelik pek çok düzenleme yapılmıştır". Sonuncusu ise "imar barışı" olarak adlandırılan 7143 sayılı kanunla yapılan düzenlemedir. 7143 sayılı kanun, belirli şartlar altında hukuka aykırı şekilde inşa edilen yapılara, yap1 kayıt belgesi verilmesini ve böylece bu tür yapıların kayıt altına alınmasını sağlamayı amaçlamaktadır. O halde öncelikle değerlendirilmesi gereken kavram, yapı kayıt belgesi ve bu belgenin hukuki niteliğidir.

\section{YAPI KAYIT BELGESİ VE HUKUKİ NİTELİĞí}

\section{Yapı Kayıt Belgesi}

7143 sayılı kanunla, 3194 sayılı İmar Kanunu'na eklenen geçici 16. maddede, yapı kayıt belgesinden söz edilmektedir. Yapı kayıt belgesi, bu kanunla hukukumuza girmiş bir kavramdır ve ruhsatsız veya ruhsat ve eklerine aykırı yapıların kayıt altına alınmasını amaçlamaktadır. Bu durumda belgenin alınabilmesi için ilk şart, yapının ${ }^{6}$ ruhsatsız veya ruhsat ve eklerine aykırı

\footnotetext{
${ }^{1}$ Paralel düzenlemeler, 5302 sayılı İl Özel İdaresi Kanunu ve 5393 sayılı Belediye Kanunu'nda da yer almaktadır.

${ }^{2}$ Tercan, s. 20.

${ }^{3}$ Tercan, s. 21.

${ }^{4}$ Günümüze kadar yapılan düzenlemelerde kanun metni içinde imar affı kavramı kullanılmamışsa da ortaya çıkan sonuçlar itibariyle durum, toplum nezdinde af olarak algılandığından, terminolojik olarak da yerleşmiştir. Tercan, s. 20; Çakır, s. 18. Bununla birlikte 7143 sayılı kanunla, 3194 sayılı İmar Kanunu'na geçici 16. madde ile eklenen düzenlemede, imar barışından söz edilmektedir.

5 İmar affı kavramı ülkemizde özellikle 1980ler'de gecekondu şeklindeki yapılaşmayı düzenlemek için daha çok gündeme gelse de bu minvaldeki kanunların 1948'ten itibaren çıkarıldığı görülmektedir. Söz konusu kanunların kronolojik sırası ve getirdiği düzenlemelere ilişsin genel bilgi için bkz. Tercan, s. 21-26.

${ }^{6}$ Yapı kavramı İmar Kanunu'nda Yapı; "karada ve suda, daimi veya muvakkat, resmi ve hususi yeraltı ve yerüstü inşaatı ile bunların ilave, değişiklik ve tamirlerini içine alan sabit ve müteharrik tesisler", Bina ise "kendi başına kullanılabilen, üstü örtülü ve insanların içine girebilecekleri ve insanların oturma, çalışma, eğlenme veya
} 
yapılmış olmasıdır. Tamamlanmış yapılar için bunu tespit "nispeten kolay"7 olduğu halde, henüz tamamlanmamış inşaat halindeki yapılar için nasıl bir değerlendirme yapılacağı geçici 16 . maddede yer almamaktadır. Bununla birlikte Yapı Kayıt Belgesi Verilmesine İlişkin Usul Ve Esaslar Tebliği'nde ${ }^{8}$ inşaat halindeki yapılar için de yapı kayıt belgesi alınabileceği düzenlenmiştir. $\mathrm{Bu}$ husus özellikle inceleme konumuz olan arsa payı karşılı̆̆ inşaat sözleşmelerinde yüklenicinin edim borcu açısından önem taşımaktadır.

Yapı kayıt belgesi alınabilmesi için aranan şartlardan diğeri, yapının 31.12.2017 tarihinden önce ve kanunun kapsamına giren alanlara ${ }^{9}$ yapılmış olmasıdır. Yapının bu tarihten önce yapıldığı konusunda, talepte bulunanın beyanı esas alınmaktadır ${ }^{10}$. Aynı şekilde geçici 16. maddede "Başvuruya konu yapının ve arsasının mülkiyet durumu, yapı sınıf ve grubu ve diğer hususlar Bakanlık tarafından hazırlanan Yapı Kayıt Sistemine yapı sahibinin beyanına göre" kaydedileceği belirtilmiştir. Bundan sonra ise "Çevre ve Şehircilik Bakanlı̆̆l ve yetkilendireceği kurum ve kuruluşlara 31/10/2018 tarihine kadar başvurulması" ve "31/12/201811 tarihine kadar kayıt bedelinin ödenmesi" gerekmektedir (m. 16). Kayıt bedelinin nasıl belirleneceği geçici 16. madde ile ilgili tebliğde ayrıntılı biçimde düzenlenmiştir ${ }^{12}$. Bakanlıkça yapılan denetimlerde bedelin eksik yatırıldığının ortaya çıkması halinde bunun tamamlattırılması, fazla yatırıldığının anlaşılması durumunda da iade yapılacağı kabul edilmiştir Ancak eksik bedel tamamlanmazsa, yapı kayıt belgesi iptal edilmektedir (Tebliğ m. 10).

Başvuru yapı maliklerinden biri veya vekili tarafindan yapılır ${ }^{13}$. Tek malik varsa onun tarafından, birden fazla malik varsa (paylı veya elbirliği) onlardan birinin başvurusu kanununa

dinlenmelerine veya ibadet etmelerine yarayan, hayvanların ve eşyaların korunmasına yarayan yapılardır” şeklinde tanımlanmıştır (m. 5).

${ }^{7}$ Çakır, s. 22.

${ }^{8}$ Yapı Kayıt Belgesi Verilmesine İlişkin Usul Ve Esaslar Tebliği (RG. 06.06.2018, S. 30443) m. 6/6 "İnşaat halindeki yapılarda 31/12/2017 tarihi itibari ile bitmiş olan kısımlar için ilave inşaat alanı ihdas etmemek şartı ile Yapı Kayıt Belgesi verilir ve Yapı Kayıt Belgesi verilen kısımların eksik inşaat işleri tamamlanabilir." Bu tebliğde 20.9.2018 tarih ve 30541sayılı resmi Gazetede ve 08.05.2020 tarih ve 31121 sayılı Resmi gazetede yayınlanan iki değişiklik yapılmıştır.

9 Kanunun kapsamına girmeyen alanlar istisna tutulmuştur. Bunlar "Üçüncü kişilere ait özel mülkiyete konu taşınmazlarda bulunan yapılar ile Hazineye ait sosyal donatı için tahsisli araziler üzerinde bulunan yapılar" (m. 16); "18/1 1/1983 tarihli ve 2960 sayll Boğaziçi Kanununda tanımlanan Boğaziçi sahil şeridi ve öngörünüm bölgesi içinde ekli kroki ile listede sinır ve koordinatları gösterilen alan ile İstanbul tarihi yarımada içinde ekli kroki ile listede sinır ve koordinatları gösterilen alanlarda ve ayrıca 19/6/2014 tarihli ve 6546 sayll Çanakkale Savaşları Gelibolu Tarihi Alan Başkanlı̆̆ Kurulması Hakkında Kanunun 2. maddesinin birinci fikrasının (e) bendinde belirlenmiş Tarihi Alanlardir"

${ }^{10}$ Yalan ve yanlış beyanda bulunulması halinde bunun hukuki ve cezai sonuçları Yönetmelik m.10'da düzenlenmiştir. Buna göre “(1) Yapı Kayıt Belgesi verilmesine ilişkin iş ve işlemler Bakanlık tarafindan denetlenebilir. (2) Yapı Kayıt Belgesi düzenlenmesi safhasında e-Devlet sistemi üzerinden veya kurum ve kuruluşlara yapılan müracaatta yalan ve yanlıs beyanda bulunanlar hakkinda 26/9/2004 tarihli ve 5237 sayll Türk Ceza Kanununun "Resmi belgenin düzenlenmesinde yalan beyan" başlıkl 206. maddesi uyarınca suç duyurusunda bulunulur. (3) Yapı Kayıt Belgesi düzenlenmesi safhasinda yalan ve yanlış beyanda bulunulan husus Yapı Kaylt Belgesi bedelinin eksik olarak hesaplanması neticesini doğurmuş ise, eksik alınan bedel ilgilisinden alınır. Eksik alınan meblağın ilgilisince ödenmemesi halinde verilmiş olan Yapı Kayıt Belgesi iptal edilir ve daha önce yatırllmış olan bedel iade edilmez."

${ }^{11} \mathrm{Bu}$ sürenin uzatılabilmesine ilişkin bakanlar kuruluna verilen yetki, cumhurbaşkanlığı hükümet sistemine geçilmesi ile (bakanlar kurulu kaldırıldığı için) 257 sayılı cumhurbaşkanlığı kararıyla 31.12.2018 tarihine uzatılmıştır.

${ }^{12}$ Geçici 16. madde fikra 2 ve ilgili tebliğin 5. Maddesi, yapı kayıt belgesi alınabilmesi için ödenecek bedeli hesaplamaya ilişkin hükümler getirmektedir.

${ }^{13}$ Yönetmelik m. 4/2 "Yapı Kayıt Belgesi için yapı maliklerinden herhangi birisi veya vekili tarafindan, e-Devlet üzerinden Yapı Kaylt Sistemindeki Yapı Kayıt Belgesi formunun doldurulması suretiyle müracaatta bulunulabileceği gibi kurum ve kuruluşlara başvurulmak suretiyle de müracaatta bulunulabilir." 
göre yeterlidir ${ }^{14}$. Tebliğin ilk halinde yer alan her yapı için sadece bir yapı kullanım belgesi düzenlenebileceği yönündeki kural, usul ve esaslara ilişkin tebliğde 20/9/2018 tarih ve 3054 sayılı Resmi Gazete'de yayınlanan değişiklikle yürürlükten kaldırılmıştır.

\section{Hukuki Niteliği}

Yapı kayıt belgesi, İmar Kanunu geçici 16. madde uyarınca yapının kullanımına yönelik bir belgedir ve bu belge, alınmış yıkım kararlarını ve idari para cezalarını ortadan kaldırır (geçici m. 16). Bununla birlikte yapı kullanım belgesi, geçici bir belgedir. Zira belgenin yapının yeniden yapılmasına veya kentsel dönüşüm uygulanmasına kadar geçerli olduğu, yapının yenilenmesi halinde yürürlükteki imar mevzuatının uygulama alanı bulacağı aynı maddenin 10. fikrasında düzenlenmiştir. Ancak bir değerlendirme yapmak için öncelikle belge talep edebilecek kişiler bakımından durumu ayrı ayrı incelemek gerekir ${ }^{15}$. Geçici 16 . maddeye göre mülkiyeti belediye veya hazineye ait olan yerlere yapı inşa edenler ve mülkiyeti kendine ait olan ancak ruhsatsız veya ruhsat eklerine aykırı yapı inşa edenler yapı kayıt belgesi alabilirler.

Mülkiyeti belediye veya hazineye ait yerlere yapı inşa edenlerin bu belgeyi alması onları malik yapar mı sorusu, belgenin hukuki niteliği ile ilgili bir problemdir. Daha önceki imar affı kanunlarıyla $^{16}$ getirilen tapu tahsis belgesi için Yargıtay'ın yaptı̆̆ı değerlendirme, yapı kayıt belgesi için de yol gösterici olabilir ${ }^{17}$. Yargıtay'a göre tapu tahsis belgesi " bir mülkiyet belgesi olmayıp yalnızca fiili kullanmayı belirleyen ve ilgilisine kişisel hak sağlayan bir zilyetlik belgesidir. Tapu tahsis belgesinin varliğl, tahsis edilen yerin, tahsis yapılan kişi veya mirasçıları adına tescili için yeterli değildir. Tahsis kapsamındaki yerin hak sahibi adına tescil edilebilmesi için; (...) Kanunda yer alan diğer şartların da var olması gerekir" ${ }^{18}$ şeklindedir. O halde mülkiyeti hazineye veya belediyeye ait yerlere yapı inşa edenlere verilen yapı kayıt belgesi de "tapuya dönüşünceye kadar, kişiler için hak sahipliğini ve fiili kullanmayı belirleyen bir zilyetlik belgesi" olarak nitelendirilebilir ${ }^{19}$. Mülkiyeti kendine ait olan ancak ruhsatsız veya ruhsat eklerine aykırı yapı inşa edenlerin aldığı yapı kayıt belgesi ise yapının hukuka uygun şekilde kullanılmasını sağlayan bir belgedir. Bu açıdan yapı kayıt belgesinin doktrinde "idarenin mülkiyetinde olan yerler üzerine inşa edilen yapılar için hak sahipliğini ve fiili kullanmayı belirleyen ve kişilerin mülkiyet hakkına sahip oldukları taşınmazları üzerinde var olan yapıdaki imar mevzuatına aykırılıkları hukuka uygun hale getiren sui generis bir belge" şeklinde tanımlandığ 1 görülmektedir ${ }^{20}$. Ancak Yargitay'ın bu belgeyi “yapının kullanılması ile ilgili maliklere bir yetki veren, yapının kullanımı ve zilyetliği hususunda idari statü sağlayan” bir belge olarak değerlendirdiği anlaşılmaktadır ${ }^{21}$.

\footnotetext{
${ }^{14}$ Paylı mülkiyet, elbirliği mülkiyeti ve kat mülkiyetine tabi yapılarda yapı kayıt belgesi için ortaya çıkabilecek problemlerin değerlendirilmesi konusunda bkz. Çakır, s. 34-36.

${ }^{15}$ Çakır, s. 44.

16 Tapu tahsis belgesi kavramı, 24/2/1984 tarihli ve 2981 sayılı İmar ve Gecekondu Mevzuatına Aykırı Yapılara Uygulanacak Bazı İşlemler ve 6785 Sayılı İmar Kanunu’nun Bir Maddesinin Değiştirilmesi Hakkında Kanun ile düzenlenmişti. Bu kanun 6306 sayılı Afet Riski Altındaki Kanunların Dönüştürülmesi Hakkında Kanun’un 23. maddesi ile yürürlükten kaldırılmıştır.

${ }^{17}$ Çakır, s. 44.

${ }^{18}$ YHGK. 4.12.1996 tarih ve 1996/14-763-864 sayılı karar (Karar için bkz. Çakır, s. 44, dpn. 88).

${ }^{19}$ Çakır, s. 45.

${ }^{20}$ Çakır, s. 46.

${ }^{21}$ HGK. 10.06.2020, 15-168/394 (Sinerji mevzuat ve İçtihat programı)
} 
Yapı kayıt belgesinin alınmasının sonuçları ise imar barışı kanunu ve ilgili tebliğin 6 . maddesinde düzenlenmiştir. Buna göre yapı kayıt belgesi her şeyden önce yapının halihazır durumunu korurken, bu durumda değişiklik yapılmasını da yapı yeniden yapılana veya kentsel dönüşüm uygulamasına kadar engellemektedir. Usul ve esaslar hakkındaki tebliğ, tamamlanan yapılarda sadece ruhsat gerektirmeyen basit onarım ve tadilatların yapılabileceğini, inşaat halindeki yapılarda 31/12/2017 tarihi itibari ile bitmiş olan kısımlar için ilave inşaat alanı ihdas etmemek şartı ile yapı kayıt belgesi verilebileceğini ve yapı kayıt belgesi verilen kısımların eksik inşaat işlerinin tamamlanabileceğini, düzenlemektedir. Bu belge ile yapıya "talep halinde ilgili mevzuatta tanımlanan ait olduğu abone grubu dikkate alınarak geçici olarak su, elektrik ve doğalgaz" bağlanabilir (Geçici m. 16/3). Belirlenen bedelin iki katının ödenmesi kaydıyla yapı ruhsatı alıp da yapı kullanma izin belgesi almamış veya yapı ruhsatı bulunmayan yapılarda, "Yapı Kaylt Belgesi ile maliklerin tamaminın muvafakatinin bulunmasl ve imar planlarında umumi hizmet alanlarına denk gelen alanların terk edilmesi halinde yapı kullanma izin belgesi aranmaksızın cins değişikliği ve kat mülkiyeti tesis edilebilir" (Geçici m. 16/5) Aynı şekilde yapı kayıt belgesi verilen yapılarda, işyeri açma ve çalışma ruhsatı yapı kullanma izin belgesi aranmaksızın verilir (Tebliğ m. 6/8).

\section{ARSA PAYI KARŞILIĞI İNŞAAT SÖZLEŞMESI}

\section{Genel Olarak}

Arsa payı karşılığı inşaat sözleşmesi, eser ve satış sözleşmesinden unsurlar taşıyan karma bir sözleşmedir ${ }^{22}$. Bu sözleşme ile ilgili doktrinde çeşitli tanımlar bulunmakla birlikte "arsa sahibinin arsasının belirli paylarının mülkiyetini, yüklenicinin arsa üzerine inşa edeceği binanın belirlenen bă̆ımsız bölümlerinin teslimi karşıllğı̆nda yükleniciye devretmeyi taahhüt ettiği"' sözleşme şeklinde tarif edilebilir ${ }^{23}$. Tam iki tarafa borç yükleyen bu sözleşmede arsa sahibi, arsa payının devri borcu altına girer ki bu eser sözleşmesindeki iş sahibinin ücret ödeme borcuna benzer. Burada ifa edilen para değil, sözleşmede kararlaştırılan arsa payıdır. Yüklenicinin edimi ise sözleşme ile kararlaştırılan bağımsız bölümleri arsa sahibine teslim etme ve buna bağlı olarak inşaatı tamamlama ve kat mülkiyetine çevirmeyi kapsar ${ }^{24}$.

Arsa payı karşı1lığı inşaat sözleşmesinin karma yapısı, sözleşmenin şekli konusu açısından da önemlidir. Zira sözleşmenin unsurlarından taşınmaz satışı hukukumuzda resmi şekle tabidir (TBK. m. 237). Eser sözleşmesi için kanunda bir şekil öngörülmemiş olmakla birlikte arsa sahibinin arsa payının mülkiyetini yükleniciye geçirme borcuna bağlı olarak bu sözleşme resmi şekilde yapılmalıdır ${ }^{25}$. 24.04.1978 tarihli ve 3/4 sayıl1 YİBK. ile "noterce düzenlenen kat mülkiyeti ya da kat irtifakı satış vaadlerinin geçerli olduğuna, bu türlü satış vaadi sözleşmesinin tapu

\footnotetext{
${ }^{22}$ Erman, s. 4; Yavuz/Acar/Özen, s. 579; Esener/Güven, s. 215; Kırca, s. 81; Kartal, s. 26; Nomer, s. 60; Gümüş, s. 113; Eren, s. 955, N. 3223. Aynı yönde "arsa payı karşsllı̆̆ inşaat sözleşmesi, iş sahibinin bir arsanın muayyen bir payının bedel olarak devri veya devri taahhüdü karşıllı̆ında, yüklenicinin bir inşa (yapı) eseri meydana getirmeyi taahhüt ettiği, tam olarak iki tarafa borç yükleyen, ivazlı, çift tipli bir karma sözleşmedir." Y. 23. HD. 26.04.2016, 3146/2658. Ayn yönde 14. HD. 04.07.2017, 11967/5639 (Lex Pera Mevzuat ve Bilgi sistemi)

${ }^{23}$ Erman, s. 1.

${ }^{24}$ Yavuz/Acar/Özen, s. 578; Erman, s. 3; Esener/Güven, s. 215; Kırca, s. 81; Kartal, s. 26; Nomer, s. 60; Gümüş, s. 113.

${ }^{25}$ Erman, s. 17; Kostakoğlu, s. 928; Yavuz/Acar/Özen, s. 584; Öz, s. 7; Reisoğlu, s. 10; Eren, s. 955, N. 3224; Arat, s. 74.
} 
memurunca düzenlenmesinin zorunlu olmadığına" karar vermiştir. Böylece arsa payı karşıllğı inşaat sözleşmesi, taşınmaz satı̧ vaadi sözleşmesi şeklinde noterlerce de düzenlenmektedir ${ }^{26}$ (Noterlik K. m. 60). Şekle aykırılık sözleşmeyi geçersiz kılmakla birlikte, bunu ileri sürmenin hakkın kötüye kullanılması teşkil edebileceği halleri gözden uzak tutmamak gerekir ${ }^{27}$.

Medeni Kanunumuz, arsa payı karşıllığı inşaat sözleşmesinin tapuya şerh edilebileceğini düzenlemiş̧ir (TMK. m. 1009). Böylece ayrı bir şerh anlaşmasına gerek kalmadan, taraflardan birinin sözleşmeye ilişkin senedi tapuya ibrazı ile sözleşmenin tapu siciline şerhi sağlanmaktadır (Tapu K. m. 26).

\section{Sözleşmenin Hüküm ve Sonuçları}

Arsa payı karşıllı̆ı inşaat sözleşmesinin tarafları, arsa sahibi ve yüklenicidir. Arsa sahibinin borcu, arsa payını devretmek ve inşaatın yapılması için kendisine düşen yükümlülükleri (arsanın teslimi gibi) yerine getirmektir ${ }^{28}$. Arsa payının devri bazı sözleşmelerde kat irtifakı kurulan arsadan inşaat tamamlanınca bağımsız bölümlere özgülenecek bir kısım payların mülkiyetinin devri şeklinde, bazı sözleşmelerde baştan arsanın tamamı veya inşaatın ulaştığı aşamaya göre kademeli devir yapılmakta, bazı sözleşmelerde ise arsa paylarının satışı vaadedilmektedir ${ }^{29}$.

Yüklenicinin borcu, inşaatı tamamlamak ve teslim etmektir. İnşaatın tamamlanması ve teslim edilmesi ile birlikte yüklenici edimini yerine getirmiş olur. Ancak kendi edimini tam olarak yerine getiren yüklenici, sözleşmeye göre arsa sahibinin yerine getirmesi gereken devir borcunu talep edebilir. Bu husus üçüncü kişilere yapılan satışlar bakımından önem taşımaktadır. Zira yüklenici inşa edeceği yapıdaki bağımsız bölümleri üçüncü kişilere satarak sermaye elde etmektedir. Bu satıştan doğan bağımsız bölümün mülkiyetini tapuda devretme yükümlülüğünü ise ancak arsa sahibi kendisine devir yaptığı takdirde gerçekleştirebilmektedir.

Edimin yüklenici tarafından yerine getirilmesi, yapının imar mevzuatına uygun yapılmasını gerektirir. Ruhsat alınmaması, ruhsata aykırı imalat yapılması, yapı kullanım belgesi alınamaması kısacası hukuka aykırı bir şekilde inşaatın yapılması, inşaat tamamlansa bile edimin ifa edildiği anlamına gelmez. Bu sebeple arsa sahibinin edimini yerine getiremeyen yükleniciye karşı duruma göre sözleşmeden dönme veya fesih imkânı doğar. O halde yüklenicinin hukuka aykırı bir inşaat için arsa sahibinin yapı kayıt belgesi almasını talep etmesi veya arsa sahibinin aldığı bu belgenin yüklenicinin edimini tam olarak yerine getirdiği şeklinde değerlendirilip değerlendirilemeyeceği hususunun incelenmesi gerekir.

\section{YAPI KAYIT BELGESİ ALINMASININ YÜKLENICININ EDIMINİ İFASINA ETKisi}

İmar mevzuatına aykırı inşa edilen veya inşaatı devam eden bir yapı için yapı kayıt belgesi alınabilir. Bir başka deyişle imar mevzuatına aykırı inşa edilen yapılar için yapı kayıt belgesi alınabileceği gibi inşaatı devam eden yapılar için de yapı kayıt belgesi alınabilir. Bu belgenin alınmasının yapının hukuki durumuna ve yüklenicinin edim yükümlülüğ̈̈ne etkisinin ne olacağı

\footnotetext{
26 Öz, s. 6, 7 .

27 30.09.1988 tarih ve 2/2 YİBK.

${ }^{28}$ Erman, s. 2; Yavuz/Acar/Özen, s. 577; Gümüş, s. 113; Arat, s. 80.

${ }^{29}$ Geniş bilgi için bkz. Erman, s. 12 vd.; Yavuz/Acar/Özen, s. 581 vd.; Gümüş, s. 114 vd.; Arat, s. 77 vd.
} 
pek çok Yargitay kararına konu olmuştur. Bu kararlar kendi içinde iki grupta toplanabilir. Özellikle kanunun yürürlüğe girdiği dönemde (2018 yılı) verilen ilk kararlarda yapı kayıt belgesinin alınmasıyla binanın hukuka uygun hale geleceği üzerinde durulurken, sonraki kararlarda belgenin sadece binanın kullanılmasına yönelik bir statü sağladığı, yapıyı imar mevzuatına uygun hale getirmeyeceği ve geçici nitelikte olduğunun vurgulandı̆̆ görülmektedir.

\section{Yargıtay'ın 2018 Yılında Verdiği Kararlar}

İmar barışı ile ilgili kanunun yürürlüğe girdiği 2018 yılındaki ilk kararlarında Yargıtay, bir inşaatın imar mevzuatına uygun yapılması gerektiğini ${ }^{30}$ ancak 7143 sayılı kanunla 3194 sayılı imar kanununa eklenen geçici 16. madde çerçevesinde alınacak yapı kayıt belgesinin geçici de olsa yapıyı yasal hale getireceğini hemen hemen aynı gerekçe ile kabul etmektedir ${ }^{31}$. Bu kararlarda şu gerekçe ortaya konulmaktadır³2: “... 18.05.2018 tarihinde yürürlüğe giren 7143 sayılı Kanun'un 16. maddesiyle 3194 sayılı Imar Kanunu'na eklenen geçici 16. madde ile yapılmış yeni bir düzenleme bulunmaktadır. Maddede; afet risklerine hazırlık kapsamında ruhsatsız veya ruhsat ve eklerine aykırı yapıların kayıt altına alınması ve imar barısının sağlanması amacıyla, 31.12.2017 tarihinden önce yapılmış yapılar için Çevre ve Şehircilik Bakanlı̆̆ ve yetkilendireceği kurum ve kuruluşlara 31.10.2018 tarihine kadar başvurulması, bu maddedeki şartların yerine getirilmesi ve 31.12.2018 tarihine kadar kayıt bedelinin ödenmesi halinde Yapı Kayıt Belgesi verilebileceği, başvuruya konu yapının ve arsasının mülkiyet durumu, yapı sınıf ve grubu ve diğer hususlar Bakanlık tarafından hazırlanan Yapı Kayıt Sistemine yapı sahibinin beyanına göre kaydedileceği (Geçici 16/1); Yapı Kayıt Belgesinin yapının kullanım amacına yönelik olduğu, Yapı Kayıt Belgesi alan yapllara, talep halinde ilgili mevzuatta tanımlanan ait olduğu abone grubu dikkate alınarak geçici olarak su, elektrik ve doğalgaz bağlanabileceği (Geçici 16/3);Yapı Kayıt Belgesi verilen yapılarla ilgili bu Kanun uyarınca alınmıs yıkım kararları ile tahsil edilemeyen idari para cezalarının iptal edileceği (Geçici 16/4); Yapı Kayıt Belgesinin, yapının yeniden yapılmasına veya kentsel dönüşüm uygulamasına kadar geçerli olduğu, Yapı Kayıt Belgesi düzenlenen yapıların yenilenmesi durumunda yürürlükte olan imar mevzuatı hükümlerinin uygulanacă̆ı, yapının depreme dayanıklılığı hususunun malikin sorumluluğunda olduğu (Geçici 16/10); bu maddenin uygulanmasına ilişkin usul ve esasların Bakanlık ve Maliye Bakanlı̆̆ tarafindan müştereken belirleneceği (Geçici 16/12) düzenlenmiş ve maddenin diğer fikralarında da uygulama esaslarl ve istisnaları belirtilmiş ayrıca bu tür yapılarda cins değişikliği ve kat mülkiyeti tesis edilebilmesi imkânı getirilmiştir, 3194 sayılı Kanun'a eklenen geçici 16. madde, 31.12.2017 tarihinden önce yapılmış imara aykırı ve kaçak yapılar için uygulanacă̆ından içeriği itibarıla geriye etkili olarak

\footnotetext{
30 “...3194 sayılı Imar Yasası'nın 21. maddesi hükmü uyarınca, bazı istisnalar dışında, bütün yapılar için belediye veya valiliklerden yapı ruhsatı alınması zorunludur. Ruhsatsı veya ruhsat ve eklerine aykırı olarak inşa edilen yapılarda ruhsata aykırılık giderilemiyorsa,3194 sayılı Yasa'nın 32. maddesi hükmü gereğince, ilgili belediye veya valilikçe insaat derhal durdurulur ve yasal hale getirilmesi olanaksı ise veya ruhsat veya eklerine ya da imar mevzuatına aykırılı öncelikle yüklenici tarafindan giderilemiyorsa bu hali ile yapılan yapının yıktırılmasına karar verilir ve anılan Yasa'nın 42. maddesi hükmü gereğince de yapı sahibine ve yükleniciye ceza yaptırımı uygulanır..." Y. 15. HD. 29.05.2018 tarih 740/2228 (Sinerji mevzuat ve içtihat programı).

${ }^{31}$ Aynı yönde 15. HD. 22.05.2018 tarih ve 784/2081 sayılı karar; 15. HD. 25.06.2018 tarih ve 821/2653 say1l karar; 15. HD. 23.05.2018 tarih ve 892/2126 sayll karar; 15. HD. 18.06.2018 tarih ve 1753/2525 say1l karar; 15 . HD. 24.05.2018 tarih ve 1813/2156 sayılı karar; 15. HD. 20.12.2018 ve 2782/5174 sayılı karar; 15. HD. 20.12.2018 tarih ve 2782/5174 sayılı karar. (Kararlar için bkz. Sinerji mevzuat ve İçtihat programı).

32 15. HD. 09.07.2018 tarih ve 694/2946 sayılı karar (Sinerji mevzuat ve İçtihat programı)
} 
uygulanması öngörülmüş bir düzenlemedir. Usuli kazanılmış hakkın istisnası olan geriye etkili bir kanuni düzenleme olması nedeniyle anılan hükmün mahkemelerce eldeki davalar için de uygulanması gerektiği gibi, yeni düzenlemenin temyiz aşamasında Yargıtay'ca da gözetilmesi gerekir. Yukarıda yapılan açıklama ve sözü edilen kurallarla birlikte somut olay değerlendirildiğinde bozma kararı gereğince yapının imara aykırı ya da kaçak olup olmadı̆̆l, imara aykırllık var ise giderilip giderilemeyeceği, bu konuda süre ve yetki verilmesi gerekip gerekmediği konusunda araştırma ve inceleme yapılması, ayrıca imara aykırı ve kaçak yapılar için Yapı Kayıt Belgesi alınarak yapının yeniden yapılmasına veya kentsel dönüşüm uygulamasına kadar geçerli olmak üzere geçici de olsa yasal hale getirilmesi imkânı getirildiğinden maddedeki süre içinde başvurulup gerekli işlemler tamamlanarak Yapı Kayıt Belgesi alınmak suretiyle yapının yasal hale getirilip getirilmediği saptanmak, suretiyle uyuşmazlığın mahkemece yeniden değerlendirilmesi gerekir". Görüldüğü gibi bu kararlarda yapı kayıt belgesinin yapıyı hukuka uygun hale getireceği üzerinde durulmuş ancak geçicilik özelliğinden bahsedilmekle birlikte buna vurgu yapılmamıştır.

\section{Yargıtay'ın 2019 ve Sonrasında Verdiği Kararlar}

2019 ve sonrası kararlara gelindiğinde belgenin geçicilik özelliğinin öne çıkarıldığı ve yapı kayıt belgesi alınsa bile bunun yüklenicinin ediminin tam ve gereği gibi ifa edildiği şeklinde değerlendirilemeyeceği düşüncesinin hâkim olduğu görülmektedir. Bunun yanında özellikle arsa pay1 karşılığı inşaat sözleşmesi açısından ortaya çıkan farklı ihtimaller de kararlarda değerlendirilmiştir. Yapı kayıt belgesinin yüklenicinin ifa borcuna etkisi konusu asıl mesele olmakla birlikte, bu belgenin hukuki niteliği, yüklenicinin bu belgeyi talep edip edemeyeceği, arsa sahibini buna zorlayıp zorlayamayacağı, yükleniciden tapuda pay devralan üçüncü kişilerin durumunun ne olacağı soruları da kararlarda tartışılmıştır. Ancak tüm bu soruların cevabı aslında yine yapı kayıt belgesinin ifaya etkisinin belirlenmesine bağlıdır.

Belgenin hukuki niteliği konusunda Yargıtay'ın değerlendirmesi diğer imar affi kanunlarında benimsenen yaklaşımdan farklı değildir. Yapı kayıt belgesinin, bir mülkiyet belgesi olmadığı, fiili kullanmayı koruyan bir zilyetlik belgesi olduğu, yapının kullanılmasıyla ilgili bir yetki vererek idari bir statü sağlandığı, bu geçici statünün yapıyı imara uygun hale getirmemekle birlikte, binanın kullanımı imkânı verdiği, geçici 16. madde ve hükmün gerekçesi birlikte değerlendirildiğinde bu sonuca kolaylıkla varılacağı belirtilmektedir ${ }^{33}$.

\footnotetext{
33 “...7143 sayılı Vergi ve Dĭger Bazı Alacakların Yeniden Yapılandırılması ve Bazı Kanunlarda Değişiklik Yapılmasına İlişkin Kanun ile 3194 sayılı İmar Kanunu'na geçici 16. madde eklenmiş ve maddenin ilk fikrasl, afet risklerine hazırlık kapsamında ruhsatsız veya ruhsat ve eklerine aykırı yapıların kayıt altına alınması ve imar barısının sağlanması amacıyla 31.12.2017 tarihinden önce yapılmış yapılar için Çevre ve Şehircilik Bakanlı̆̆ ve yetkilendireceği kurum ve kuruluşlara 31.10.2018 tarihine kadar başvurulması, bu maddedeki şartların yerine getirilmesi ve 31.12.2018 tarihine kadar kayıt bedelinin ödenmesi halinde yapı kayıt belgesi verilebilir hükmünü içermektedir. 3194 sayıl Kanunu'nun 5.maddesinde, yapı;" karada ve suda, sürekli ya da geçici, resmi ve özel, yerüstü veya yeraltı, inşaatı ile bunların eklerine, değişikliklerine, onarımlarına, sabit ve haraketli tesislerine verilen ad" olarak tanımlanmış, yapı kayıt belgesi ifadesi ise hukukumuza ilk olarak Imar Kanunu'na eklenen geçici 16. madde düzenlemesi ile girmiştir. 1948 yılından bu yana kaçak yapı olarak tabir edilen imara aykırı yapılaşma hususunda birçok kanun çıkmış ve çıkan bu kanunlarda, imar alanında ve imar kanununda birtakım de ğişiklik ve düzenleme içererek, bu yapıların kullanımına ilişkin yasal bir statü getirdiğinden, imar affi olarak anılmıştır. Genel olarak imar affi; yürürlükte bulunan imar hukukuna ilişkin yasalara uyulmayarak yapılan yapıların mevcut durum ve konumlarıla mevcut imar mevzuatına uyulması beklenmeksizin, koşullara uygun olanların mevcut haliyle korunması
} 
Yap1 kayıt belgesinin kim tarafından alınabileceği konusu da kararlarda değerlendirilmiştir. Geçici 16. maddeye göre yapı kayıt belgesi, malik tarafindan talep edilebilecektir. $\mathrm{Bu}$ emredici bir hüküm değildir ve malikin mutlaka yapı kayıt belgesi almak zorunluluğu da bulunmamaktadır ${ }^{34}$. Kararlarda arsa payı karşılı̆̆ türlerinden biri olan sözleşmenin kurulmasıyla birlikte edim ifa edilmeden, arsa payının yükleniciye devredildiği durumlarda, yüklenici bu payların maliki olarak yapı kayıt belgesi alabilir mi sorusuna olumsuz cevap verilmiş, Yargıtay'ın yerleşik uygulamasının bu durumu avans olarak nitelendirdiği, yüklenicinin karşı edimini ifa ettiği takdirde şahsi hak elde edeceği ve bunu üçüncü kişilere devredebileceği, yüklenici yapı kayıt belgesi alsa bile bu onun edimini ifa ettiği anlamına

ve bu şekilde bir statü sağlanmasıdır (Çakır, Hüseyin Melih, Yapı Kayıt belgesi, İstanbul Medipol Üniversitesi Hukuk Fakültesi Dergisi, cilt 5, sayı 2, 2018, s.15-92). 3194 sayll kanuna eklenen geçici 16. maddenin de, daha önce çıkarılan imar affi niteliğindeki yasalar gibi kaçak binalara hukuki bir koruma să̆layıp sağlamadı̆̆l, yasada yer almamakla birlikte literatürde kabul gördüğ̈̈ gibi "bir imar affi” olarak kabulünün mümkün olup olmadiğının değerlendirilmesi gerekir. Daha önce çıkarılan ve imar affı olarak tabir edilen yasal değişikliklerle getirilen statünün bir mülkiyet belgesi olarak kabulü mümkün değildir. Daha önce gecekondu affi olarak da değerlendirilen yerlere ilişkin verilen tapu tahsis belgesi bir mülkiyet belgesi olarak değil, ilgili taşınmaz üzerindeki fiili kullanmayı koruyan bir zilyetlik belgesi olarak kabul görmüştür (Hukuk Genel Kurulu'nun 04.12.1996 tarih ve 1996/14-763-863 sayll kararlarında belirtildiği üzere).3194 sayılı Yasaya eklenen geçici 16. maddenin gerekçesi de "afet risklerine hazırlık kapsamında ruhsatsız, ruhsat ve eklerine aykır veya imar mevzuatına aykır yapıların kayıt altına alınması ile dönüşüm projelerine finans sağlanarak, dönüşümün daha hızlı ve etkin yapılması amacıyla 31.12.2007 tarihinden önce yapılmış yapıların, yapı sahiplerinin müracaatları üzerine ve beyanına göre hazırlanacak yapı kayıt sistemine islenmesi, bu yapılara su, elektrik ve doğalgaz bă̆lanabilmesi için yargı ve belediyelerdeki is yükünün azaltılabilmesi için alınmış yıkım kararlarından ve tahsil edilmeyen para cezalarından vazgeçilmesi, maliklerin yarısının mutabakatının bulunması halinde yapı kullanma izin belgesi aranmaksızın cins değişikliği ve kat mülkiyeti tesis edilebilmesi" olarak belirtilmiştir. Madde, bir bütün olarak gerekçesi ile birlikte değerlendirildiğinde, imara aykırı yapılarla ilgili bu belgenin başvuru sonucu verilmesiyle, yukarlda mülkiyet hakkının kişiye să̆ladiğ haklardan niteliği ile ilgili kullanma hakkı konusunda, yapının kullanılması ile ilgili maliklere bir yetki verildiği, yapının kullanımı ve zilyetliği hususunda idari bir statü să̆landığı anlaşılmaktadır. Yapı kayıt belgesi verilmekle sağlanan bu statü, imar mevzuatına aykırı olması nedeniyle korunmayan ve aslında yıkılmasi gereken bir yapının kullanılması konusunda, yapı malikine idare tarafindan bir koruma sağlamaktadır. Imara aykırı yapıyı imara uygun yasal bir statü getirmemekle birlikte, yapı sahibine binanın kullanımı konusunda olanak sağlamaktadır. Zira geçici 16. maddenin 3. fikrasında da, yapı kayıt belgesinin yapının kullanım amacına yönelik olduğu açıkça belirtilmiştir. Bu hususlar dikkate alındı ğında, düzenlemenin, mülkiyet hakkına sınırlama getirmekten öte, imara aykırı olup yıkılması gereken yapıların kullanılmasına müsaade ederek, genişlettiğini söylemek ileri bir yorum olmayacaktır. Bir anlamda idare, imara aykırı yapının kayıt altına alınması şartıyla, mer'i mevzuata göre yıkılması, kullanımını sağlayan aboneliklerin tesis edilmemesi, kaçak yapının yıkılması hususlarında kendisini sınırlamakta ve yapı malikine bu kurallara uyulmaksızın yapının kullanılmasına olanak sağlamaktadır. Yine geçici 16. maddenin 10. fikrasında yapı kayıt belgesinin, yapının yeniden yapılmasına veya kentsel dönüşüm uygulamasına kadar geçerli olduğu, yapı kayıt belgesi düzenlenen yapıların yenilenmesi durumunda yürürlükte olan imar mevzuatı hükümleri uygulanacağı açıç̧a belirtilmiştir. Bu hüküm özellikle yapı kayıt belgesinin, yapının kullanılmasına ilişkin geçici bir statü sağladığı, yapının bu statü ile imara aykırı olmasına karsın idare tarafindan kullanılmasına izin verildiği, ancak yenilenmesi durumunda yürürlükte olan imar mevzuatı hükümlerinin uygulanmasını öngörmekle imar affı olarak değerlendirilemeyeceğini açıç̧a ortaya koymaktadır...” 15. HD. 23.05.2019 tarih ve 5361/2479 sayılı karar; aynı yönde Y. 15. HD. 21.09.2020 tarih ve 3962/2494 sayılı karar; YHGK. 10.06.2020 tarih ve 15-168/394 say1lı karar (Sinerji mevzuat ve İçtihat programı). 34 “...yapı kayıt belgesi için kimin başvuru yapabileceği sözleşmeyle kararlaştırılan edimlerin ifasına etkisini değerlendirmek gerekir. Geçici 16. maddenin ilk fikrasında belirtilen şartların taşınması halinde yapı kayıt belgesi verilebileceği hüküm altına alınmıştır. Burada taşınmaz malikine getirilmiş bir hak bulunmakta olup, bu hakkın kullanılması konusunda emredici bir ifade bulunmamaktadır. Bu durum dikkate alındığında, hiçbir kimse kendi rızası dışında, yapı kayıt belgesi almak için başvuru yapmaya zorlanamayacaktır. Karşılıklı edimler içeren bir arsa payı karşılı̆̆ inşaat sözleşmesinde de, yüklenici imara aykırı olarak yapmış olduğu binaya yapı kayıt belgesi alması hususunda arsa sahibini zorlayamayacaktır..." Y. 15. HD. 23.05.2019 tarih ve 5361/2479 say1lı karar; aynı yönde YHGK. 10.06.2020 tarih ve 15-168/394 sayılı karar (Sinerji mevzuat ve İçtihat programı). 
gelmeyeceğinden, ayni hakkı da kazanmış sayılmayacağından böyle bir talepte bulunamayacağı sonucuna varılmıştır ${ }^{35}$.

Yükleniciden tapuda pay devralan üçüncü kişilerin durumuna yap1 kayıt belgesi alınmasının etkisine gelince, bilindiği gibi Yargıtay’ın yerleşik uygulamasına göre bu kişilerin arsa sahibinden tapuda kendisine pay devri yapılmasını isteyebilmesi, yüklenicinin edimini tam olarak yerine getirmesine bağlıdır. Yükleniciden pay devralan üçüncü kişi, yüklenicinin arsa sahibinde olan ve arsa payı karşılığı inşaat sözleşmesinden doğan alacağını devralmakta, böylece aralarında bir temlik (alacağın devri) ilişkisi doğmaktadır. Yargıtay’a göre yüklenici edimini gereği gibi ifa etmemekle birlikte yapı kayıt belgesi ile inşaatın hukuka uygun hale gelmesi, onun edimini ifa ettiği anlamına gelmeyeceğinden temlik alan üçüncü kişinin arsa sahibinden mülkiyetin devrini istemesi de söz konusu olmamaktadır. Zira yüklenici arsa sahibinden karşı edimi elde edememiştir ve elde edemediği hakkı başkasına devredemez, üçüncü kişi de arsa sahibini buna zorlayamaz ${ }^{36}$.

35 “...kat karşılı̆̆ inşaat sözlesmelerinde, bazı durumlarda sözlesmenin kurulmasıyla, henüz yüklenici tarafindan edimin ifasına başlanmadan taşınmazda hisse devri yapılabilmektedir. Sinerji Mevzuat ve İçtihat Programı Sayfa 4 16 Yüklenici tarafindan edimin ifasına başlanmadan veya edim ifa edilmeden taşınmazda hisse devri yapılması veya taşınmazın tüm olarak devredilmesinde, yüklenicinin malik olma durumunu öne sürerek yapı kayıt belgesi alması ve buna göre ifa yükümlülüğ̈̈nü yerine getirdiğini ileri sürmesi ayrı bir sorun olarak ortaya çıkmaktadır. Yargıtay Hukuk Genel Kurulunun 04.11.2015 tarih ve 2014/6-324 esas, 2015/2787 karar sayılı ilamında, “Arsa payı karşılı̆̆ inşaat yapım sözleşmesi gereğince, arsa sahibi tarafından yükleniciye ya da onun istemiyle üçüncü kişi veya kişilere yapılan taşınmaz ya da taşınmaz payı temliki, inşaatın yapımı için finans sağlanması amacılla verilen "avans" niteliğinde olup; yüklenici yüklendiği karsı edimini ifa ettiği oranda "şahsi hak" elde edebilir ve ancak kazandiğ şahsi hakkını üçüncü kişilere temlik edebilir. Yüklenici, tüm edimlerini ifa ettiği takdirde ve sözleşmenin de ifa ile sonuçlanması durumunda şahsi hakkl, aynî hakka dönüşür. Nitekim arsa payı karşıllğı inşaat yapım sözleşmesi nedeniyle yükleniciden pay iktisap eden üçüncü kişiler, Türk Medeni Kanunu'nun 1024. maddesi ve aynı Kanun'un 1023. maddesi hükmünden yararlanamazlar. Inşaatın

hukuki anlamda teslimine kadar arsa sahibi avans olarak verdiği payları geri alma hakkına sahiptir. Hukuki teslim ise, yapılan inşaatın yasal mevzuata uygun olarak bitirilmesi (iskân izninin alınması) halinde gerçekleşmiş sayılır”, ifadesi ile açıkça edimin tamamen ifa edilmesi ile aynî hakka sahip olacağını kabul etmiştir. Dairemizin istikrarlı olarak kabulü ve uygulaması da bu yöndedir. Bu haliyle yüklenicinin, kendisine devredilen hisseye dayanarak yapı kayıt belgesi alması ve buna dayanarak sözleşmeyle kararlaştırılan edimi ifadan kaçınması veya yapı kayıt belgesinin alınması ile sağlanan statüden yararlanarak ediminin ifa durumunun değerlendirilmesini talep etmesi kabul edilemez. Geçici 16. maddenin 9. bendinde de, üçüncü kişilere ait özel mülkiyete konu taşınmazlarda bu madde hükümlerinin uygulanmayacă̆ belirtilmiştir. Arsa payı karşılı̆̆ inşaat yapım sözleşmesi gereğince hisse devrinde de hukuki teslim ve aynî hak devri gerçekleşmediğinden, üçüncü kişi olarak değerlendirilebilecek olan yüklenicinin başvurusuna değer verilmesi ve sözleşmeyle kararlaştırılan edimlerin ifası nezdinde değerlendirmeye alınması mümkün olmayacaktır..." Y. 15. HD. 23.05.2019 tarih ve 5361/2479 say1l karar (Sinerji mevzuat ve İçtihat programı).

36،...Davacının arsa sahibi ile yüklenici arasında düzenlenen arsa payı karşılı̆̆ inşaat sözleşmesi gereğince yükleniciye bırakılması kararlaştırılan bă̆ımsız bölümü yükleniciden temlik alması halinde arsa sahibini ifaya zorlayabilmesi için bazı koşulların varlı̆̆ gerekir. Türk Borçlar Kanunu'nun 188. maddesi gereğince; "Borçlu, devri ögrendiği sırada devredene karsı sahip olduğu savunmaları, devralana karsı da ileri sürebilir.” Buna göre temliki ögrenen arsa sahibi, temlik olmasaydı önceki alacaklıya (yükleniciye) karsı ne tür defiler ileri sürebilecekse, aynı defileri yeni alacakllya (temlik alan davacıya) karsı da ileri sürebilir. Temlikin konusu, yüklenicinin arsa sahibi ile yaptı̆̆ sözleşme uyarınca hak kazandı̆̆l gerçek alacak ne ise o olacağından, temlik eden yüklenicinin arsa sahibinden

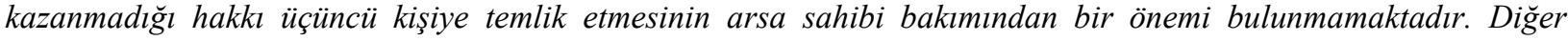
taraftan, yüklenici arsa sahibine karsı edimini tamamen veya kısmen yerine getirmeden kazanacă̆ şahsi hakkı üçüncü kişiye (davacıya) temlik etmişse, üçüncü kişi (davacl) Türk Borçlar Kanunu'nun 97. maddesi hükmünden yararlanma hakkı bulunan arsa sahibini ifaya zorlayamaz... Somut olayda ise; Uyuşmazlık, yüklenicinin edimini yerine getirip getirmediği, dolayısıla dava konusu taşınmazla ilgili olarak yüklenicinin halefi olan davacının talepte bulunup bulunamayacağı noktasında toplanmaktadır.

Arsa sahipleri ile yüklenici arasında imzalanan 11.01.1996 tarihli kat karşıllı̆ inşaat yapım sözleşmesinin 3. maddesinde aşamalı devir öngörülmüş ise de, 3/d maddesinde geriye kalan bir dükkân ve bir daire ile yükleniciye ait tüm hissenin tapusunun inşaatın yapılıp bitirildiğinde arsa sahiplerine ait bağımsız bölümlerin anahtar teslimi olarak teslim edilip kat irtifakı yapılıp iskân alındıktan sonra devredileceğinin kararlaştırıldı̆̆ı, davalı yükleniciye 
Yapı kayıt belgesinin arsa payı karşılığı inşaat sözleşmelerinde yüklenicinin ifa borcuna etkisi konusunda ise Yargıtay, bu belgenin binanın kullanımına yönelik olduğu, yapıyı imara uygun hale getirmeyeceği, imar barışı kanununda da belirtildiği üzere belgenin yapıyı kentsel dönüşüm veya yeniden yapılana kadar kullanılabilir kıldığını, yüklenicinin imara aykırı yapı inşa ettiğinde, yapı kayıt belgesi ile ifa borcunu yerine getirdiğini ileri sürmesinin, aslında edimin ifasının yapı tekrar yapılana kadar ertelenmesi anlamına geleceğini, bunun ifanın gerçekleşmediğinin göstergesi olduğunu ve hakkın kötüye kullanılması teşkil edeceği görüşündedir. Bu sebeplerle Yargıtay, arsa payı karşılığı inşaat sözleşmelerinde İmar Kanunu'na eklenen geçici 16. madde ile getirilen yapı kayıt belgesi alınabilme imkanının, yüklenicinin edimini ifasına bir etkisi bulunmadığı sonucuna varmaktadır ${ }^{37}$.

sözleşmenin 3/a,b,c bentlerinde gösterilen bağımsız bölümlerin devirleri yapılmış olup, dava konusu taşınmaza inşaatın tamamlanıp yapı kullanma izin belgesinin alınması ile hak kazanacă̆l, 3194 sayılı İmar Kanunu'nun geçici 16. maddesine göre alınan yapı kayıt belgesinin yapı kullanma izin belgesi yerine geçmeyeceğinden, bu yükümlülüğ̈̈n yerine getirildiğinin kabul edilemeyeceği, mahkemece raporlarl hükme esas alınan bilirkişi kurulundan ek rapor alınıp, ilgili belediyeden de araştırlmak suretiyle bu husus incelendikten sonra gerekirse davacıya yapı kullanma izin belgesi almak üzere makul süre ve yetki verilip, yapı kullanma izin belgesi alınması halinde tapu iptal ve tescile karar verilmesi, mümkün olmaması halinde ise tapu iptal tescil isteminin reddine karar verilmesi gerekir." Y. 15. Hukuk Dairesi, 07.12.2020 tarih ve 129/3124 sayılı karar; aynı yönde Y. 15. HD. 21.09.2020 tarih ve 3962/2494 sayıl1 karar; Y. 15. HD. 07.12.2020 tarih ve 129/3124 sayılı karar (Sinerji mevzuat ve İçtihat programı).

37 “...yapı kayıt belgesi imara aykırı yapının kullanılmasına ilişkin olup, imara uygun hale getirmemektedir. Geçici 16. maddenin 10 bendinde belirtildiği üzere, yapı kayıt belgesi, yapının yeniden yapılmasına veya kentsel dönüşümüne kadar geçerlidir. Düzenlemenin amacı da, yapının yeniden yapılmasına kadar kullanımına idare tarafindan imkân sağlanmasından ibarettir. Aksi takdirde, imara aykırı bir yapı yapmış olan yüklenicinin, yapı kayıt belgesi alındı̆̆ını ileri sürerek, ediminin ifasını yapının tekrar yapılmasına kadar ertelemiş olur ki, bu durum baslı basına edimin ifa edilmediğini gösterir. Edimin ifasının, yapının tekrar yapılmasına kadar beklenmesini talep etmekte kabul edilemez bir durumdur ve hakkın kötüye kullanılması niteliğindedir. Netice itibariyle, İmar Kanunu'na eklenen geçici 16. madde ile getirilen düzenlemenin, arsa payı karşılı̆̆ inşaat yapım sözleşmelerinde kararlaştırılan edimlerin ifasına bir etkisinin bulunmadı̆̆ sonucuna varmak mümkündür. Tabi ki sözleşme hürriyeti gereğince, tarafların yapı kayıt belgesi alınması sonrasında kavuştukları yeni durum karsısında, karşılıklı olarak edimlerinin ifa durumunu değerlendirmeleri ve mevcut duruma göre yeni bir tavır takınmaları da mümkündür. Tüm bu anlatılanlar nezdinde, davaya konu olaya döndüğ̈̈müzde; taraflar arsında imzalanan 05.04.2000 tarihli sözleşmede, yüklenici tarafindan binanın projeye uygun, anahtar teslimi ve iskânı alınmış şekilde bitirileceği kararlaştırılmıştır. Arsa payı karşılığ inşaat sözleşmelerinde, arsa sahibinin edimi, inşaat yapımına uygun olarak arsayı teslim etmek, yüklenicinin edimi ise sözleşmede kararlaştırılan şekilde inşaatı yaparak bağımsız bölümleri arsa sahibine teslim etmekten ibarettir. İskan alınmayan velveya iskân alınmaya uygun olmayan bir binanın ekonomik bir değeri bulunmamaktadır. Bu durumda, ĕger sözleşmede iskân alınması kararlaştırılmış ve iskân alınmamışsa yüklenicinin edimini ifa ettiğini kabul etmek mümkün olmayacaktır. Davaya konu olayda da iskân alınması sözleşmede kararlaştırılmış olup, yüklenici iskân almadı̆̆ından edimin ifa edildiği kabul edilemeyecektir. İki tarafa borç yükleyen arsa payı karşılı̆̆ inşaat sözleşmelerinde, inşaat belirli bir asamaya gelmiş ise ifanın tamamlanmasını beklemek ve gerekiyorsa dava açılması halinde de bu konuda firsat tanıyarak ifaya olanak tanımak hakkaniyete uygun ise de, is sahibi için de bu beklemenin bir tahammül sınırı bulunmaktadır. Dava açıldığında, yüklenici tarafından sözleşmede kararlaştırıldı̆̆ı gibi ifa yerine getirilmemiş olup, ilk derece mahkemesince de 11.04.2000 tarihli duruşmada, davalı tarafa iskân alınması için dört aylık süre verilmiştir. Verilen süre içinde gereği yerine getirilmediğinden davanın kabulüne karar verilmiştir. İstinaf edilmesi üzerine, istinaf mahkemesince de, ... Belediyesi'ne iskân alınma koşulları sorulmuş ve verilen cevaba göre de, yükleniciye tadilat avan projesi hazırlamast ve belediyeye başvuru yaparak iskân alması için süre ve yetki verilmiş, ancak netice alınmamasına rağmen 3194 Sayıl Kanun'a eklenen geçici 16. madde dikkate alınarak, kaçak yapının geçici olarak da olsa yasal hale geldiği kabul edilerek istinaf isteminin kabulüne karar verilmiştir. Yukarıda detaylı olarak açıklandığı üzere, yapı kayıt belgesi alınması, idare tarafından kaçak yapının kullanılmasına imkân tanırken, imara ilişkin mer'i mevzuatta bir değişiklik yapmadığından, iskân alınmayan/alınamayan yapının yasal hale geldiğini kabul etmek mümkün değildir. Diğer yönden, taraflar arasındaki sözleşmede iskân alınması kararlaştırılmış olup, yüklenici tarafindan edimin ifası ancak iskân alınarak taşınmazın teslimi ile mümkün olabilir. Yapı kayıt belgesi alınmış olup olmamasının karşılıklı edimlerin ifasına bir etkisi bulunmamaktadır. Yüklenici tarafindan da edimin ifa edilmemesi halinde arsa sahibi, borçlar kanununun tanıdiğı sözleşmeden dönme ve diğer haklarını kullanabilecektir. Arsa sahibi, yüklenicinin edimini ifa etmemesi nedeniyle yasadan kaynaklanan fesih hakkını kullanmış olup, 


\section{Değerlendirme}

Ülkemizde yıllardır imar affı niteliği taşıyan kanunlar çıkarılmaktadır. Genellikle kanunların adında af kelimesi geçmese de sonuçları itibariyle imar mevzuatına aykırı yapılan, hazineye ait araziler üzerinde yapılan veya inşa halinde olan yapılar, toplumsal barış, gelir ihtiyacı, fiili durumun hukuki duruma dönüştürülmesi gibi bir takım gerekçelerle hukuka uygun hale getirilmekte, kanunların öngördüğü yaptırımlardan kurtulmaktadır. Bunlardan sonuncusu 7143 sayılı Vergi ve Diğer Bazı Alacakların Yeniden Yapılandırılması ve Bazı Kanunlarda Değisşiklik Yapılmasına İlişkin Kanun ile 3194 sayılı İmar Kanunu'na geçici 16. madde ile getirilen düzenlemedir. İmar barışı olarak adlandırılan bu düzenleme ile ruhsatsız veya ruhsat eklerine aykırı yapılar için öngörülen tarih ve öngörülen bedelin ödenmesi ile yapı kayıt belgesi verilebileceği düzenlenmiştir (Geçici m. 16/1). Aynı hükümde belgenin yapının kullanım amacına yönelik olduğu, bu belgeyi alan yapılara su, elektrik, doğalgaz bağlanabileceği belirtilmiştir (Geçici m. 16/3). Aynı şekilde yapı kayıt belgesi ile yapı ruhsatı almış ancak yapı kullanma izin belgesi almamış veya yapı ruhsatı bulunmayan yapılarda, maliklerin tamamının muvafakatinin bulunması ve imar planlarında umumi hizmet alanlarına denk gelen alanların terk edilmesi suretiyle yapı kullanma izin belgesi aranmaksızın cins değişikliği ve kat mülkiyeti kurulmasına da izin verilmiştir (Geçici m. 16/5). Yapı kayıt belgesine sahip olmanın getirdiği bu imkanlar, yapının bu andan itibaren tamamen hukuka uygun hale geldiği ve süreklilik arz ettiği sonucuna varmamıza sebep olabilir. Ancak Geçici 16. maddenin 10. bendinde yapı kayıt belgesinin, yapının yeniden yapılmasına veya kentsel dönüşüm uygulamasına kadar geçerli olacağı ve yapının yenilenmesi durumunda yürürlükte olan imar mevzuatı hükümlerine tabi olacağının düzenlenmesi, belgenin geçici niteliğini ortaya çıkarmaktadır. Bununla birlikte herhangi bir yenileme veya kentsel dönüşüm olmadığı takdirde yapı mevcut haliyle imar mevzuatıyla ilgili herhangi bir hukuki yaptırıma maruz kalmayacaktır. Belge malike, doğrudan yapının kullanımını sağlamış olacaktır.

Yapı kayıt belgesinin arsa payı karşılığı inşaat sözleşmeleri bakımından ortaya çıkardığ sorun, yüklenicinin edim borcunun ifası noktasında ortaya çıkmaktadır. Yapı kayıt belgesi yapının kullanımını sağladığı, aboneliklerin bağlanmasına imkân verdiği için aslında imar mevzuatına uygun yapılmayan bir yapı, yapı kayıt belgesi ile fiilen kullanılabilir hale geldiğinden, yüklenici açısından da edimini yerine getirmiş olma sonucunu doğurur mu sorusunu akla getirmektedir. Nitekim bu yönde talepler mahkemelerin önüne gitmiş, arsa sahiplerinin yüklenicinin edimini imar mevzuatına ve sözleşmeye uygun şekilde yapmadığı gerekçesiyle açılan davalarda, yükleniciler

mahkemece bu hakkının kullanılmasının yerinde olup olmayacağı değerlendirilecektir. Yapı kayıt belgesi alındı diye, fesih hakkını kullanmasının yerinde olup olmadı̆̆ değerlendirilmeden, doğan zararına karsın tazminat hakkını kullanabileceğini gerekçe göstererek davanın reddi de doğru olmamıştır. Arsa sahibinin bu hakkını kullanması karsısında, dava sırasında da yükleniciye ediminin ifası hususunda firsat tanınması mümkün ise de makul ve katlanabilir bir sürenin verilmesi gerekir. Dosya kapsamına göre ilk derece mahkemesinde de istinaf mahkemesinde de gerekli ve uygun süre verilmiş, ancak netice alınamamıștır. Netice itibariyle dava sırasında da yükleniciye edimini ifa etmesi için süre verilip firsat tanınmış, ancak edimin ifa edilmesi hususunda gereği yerine getirilmemiștir. Yap kayıt belgesi alınması nedeniyle, yapının yeniden yapılması veya kentsel dönüşüme kadar da ifanın yerine getirmesinin askıda kalmasını arsa sahibinden beklemek Borçlar Kanunu'nun ifaya iliş̧kin hükümlerine de sözleşmeye de hakkaniyete de uymamaktadır. Tüm bu hususlar dikkate alındı̆̆ında davacının davasında hakl olduğu ve davanın kabulü gerektiğgi anlaşıldiğından davacının temyiz isteminin kabulü ile usul yasaya uygun olmayan Bölge Adliye Mahkemesi kararının bozulması uygun görülmüş̧tür." Y. 15. HD. 23.05.2019 tarih ve 5361/2479 say1l karar; aynı yönde Y. 15. HD. 21.09.2020 tarih ve 3962/2494 sayılı karar; YHGK. 10.06.2020 tarih ve 15-168/394 sayılı karar (Sinerji mevzuat ve İçtihat programı). 
bina için yap1 kayıt belgesi alınabileceğini ve böylece yapının kullanılabilir hale geleceği savunmasını yapmışlardır. Ancak Yargıtay’ın da 2019 ve sonrası kararlarında belirttiği gibi yapı kayıt belgesi, yapının imar mevzuatına uygun yapıldığını gösteren bir belge değil, mevcut haliyle kullanımını sağlayan bir belgedir. Ruhsat eksiklikleri veya yapı kullanım belgesine ilişkin eksiklikler, yapı kayıt belgesi ile giderilmez. Bu eksiklikler halihazırda mevcut olmakla birlikte yapının bu haliyle kullanılmasına izin verilmiştir. Dolayısıyla belgenin varlığı yüklenici açısından edimin ifa edildiği anlamına gelmemektedir. Bu sebeplerle Yargıtay'ın 2019 ve sonrası kararlarının düzenlemenin amacına daha uygun olduğu görülmektedir.

\section{V.SONUC}

İmar barışı düzenlemesi, ülkemizde zaman zaman çıkarılan mevcut yapıların hukuki durumunu düzeltmeye yönelik kanunların sonuncusudur. $\mathrm{Bu}$ tür kanunların kapsamının her seferinde daha genişlemesi, toplumsal sonuçları ve çevreye etkileri bakımından haklı olarak eleştirilmektedir.

Yapı kayıt belgesi, hukukumuza imar barışı kanunu ile giren yeni bir kavramdır. Bu sebeple belgenin hukuki niteliğinin belirlenmesi, ortaya çıkardığı sonuçların değerlendirilmesi önem taşır. Yargıtay kararlarında yapı kayıt belgesinin, geçici 16. madde ve kanunun gerekçesi birlikte değerlendirildiğinde "yapının kullanılmasına ilişkin geçici (yapının yeniden yapılmasına veya kentsel dönüşüm uygulamasına kadar geçerli) bir statü sağlayan, yapının bu statü ile imara aykırı olmasına karsin idare tarafindan kullanılmasına izin verilen", "yapının kullanımı ve zilyetliği hususunda idari statü" sağlayan bir belge olduğu belirtilmektedir. Böylece yapı kayıt belgesi ile imar mevzuatına aykırı olan yapı, kullanılabilecek ancak belge yapıyı imar mevzuatına uygun hale getirmeyecektir. Sağlanan bu statü ile aslında yıkılması gereken bir yapıya koruma getirmektedir.

$\mathrm{Bu}$ çerçevede ortaya çıkan sorunlardan biri arsa payı karşılığı inşaat sözleşmesinde yapı kayıt belgesi alınmasının yüklenicinin edimi ifa borcunu etkileyip etkilemeyeceğidir. Yapının kullanılmasına yönelik geçici yetki veren bir belge, yüklenicinin imar mevzuatına uygun şekilde yapmadığı bir yapıyı, mevzuata uygun hale getirmez. Bu belge yükleniciyi, edimini ifa etmiş olarak kabul etmek için yeterli değildir. Yüklenici ancak edimini tam olarak yerine getirdiğinde borcundan kurtulmuş olur.

Sonuç olarak Yargitay’ın da haklı olarak belirttiği gibi 3194 sayılı İmar Kanunu’nun geçici 16. Maddesi ile getirilen yapı kayıt belgesi, yapının kullanımına yöneliktir. Verilen bu kullanma statüsü yapıyı imara uygun hale getirmediği gibi yüklenicinin edim borcunu da etkilemez. 


\section{KAYNAKÇA}

Arat, A. Konut Satışında Üç Köşeli İlişkilerden Doğan Sorumluluk, İstanbul 2018.

Çakır, H.M, Yapı Kayıt Belgesi, İstanbul Medipol Üniversitesi Hukuk Fakültesi Dergisi, Cilt 5, Say1 2, 2018, s.15-92.

Eren, F.: Borçlar Hukuku Özel Hükümler, Ankara 2019.

Erman, H. Arsa Payı Karşıll̆̆̆ İnşaat Sözleşmesi, İstanbul 2010.

Esener, T./Güven, K. Eşya Hukuku, Ankara 2015.

Gümüş, M. A. Borçlar Hukuku Özel Hükümler, C. 2, İstanbul 2014.

Kartal, B. Kat Karşıllı̆̆ İnşaat Sözleşmesi, Ankara 1993.

Kırca, Ç. Arsa Payı Karşıllğ̆ İnşaat Sözleşmelerinde Sözleşmeden Dönmenin Üçüncü Kişilere Etkisi, XXII. Ticaret Hukuku ve Yargıtay Kararları Sempozyumu, Bildiriler-Tartışmalar, Ankara 2007.

Kostakoğlu, C. İ̧̧tihatlı İnşaat Hukuku ve Kat Karşıllı̆̆ İnşaat Sözleşmeleri, Ankara 2008.

Nomer, H. N. Borçlar Hukuku Genel Hükümler, İstanbul 2015.

Öz, T. İnşaat Sözleşmesi ve Illgili Mevzuat, İstanbul 2016.

Reisoğlu, S. Arsa Payı Karşılığı İnşaat Sözleşmesine İlişkin Bir Kısım Sorunlar, BATIDER. C. XXIV, S. 21, 2007.

Tercan, B. 1948'den Bugüne İmar Afları, Mimarlı, Y. 55, S. 403, Eylül-Ekim 2018.

Yavuz, C./Acar, F./Özen, B. Borçlar Hukuku Dersleri (Özel Hükümler), İstanbul 2018. 